\title{
Somogy megye fejeslegyeinek katalógusa (Diptera: Conopidae)
}

\author{
TÓTH SÁNDOR
}

Tóth S.: Checklist of thick-headed flies of Somogy county (Diptera: Conopidae)

Abstract: Out of the 40 thick-headed fly species recorded in Hungary, 25 taxa are proved to be found in Somogy county. The fauna of the area is poorly known. Some of the relatively rare species known from this area are Conops vesicularis Linnaeus, 1761, Dalmannia dorsalis (Fabricius, 1794), Leopoldius coronatus (Rondani, 1857), Myopa polystigma Rondani, 1857, Thecophora distincta (Meigen, 1824), Zodion notatum (Meigen, 1804).

\section{Bevezetés}

Magyarország fejeslegyeinek kutatottságát jónak nevezhetjük, azonban a faunáról összefoglaló tanulmány még nem készült. A fajok száma mintegy 40-re becsülhetô. A régebbi faunisztikai irodalomban nem sikerült Somogy megyére vonatkozó fejeslégy közlést találni. Csupán a területen szervezett programok keretében készült 3 dolgozat (CSIBY 1981, TóTH 1992, 1995), továbbá a publikálatlan adatokból összeállitott kézirat (TóTH elókészületben) tartalmaz idevágó adatokat. Ennek figyelembe vételével, Somogy megyéból jelenleg 25 fejeslégy faj elöfordulását tekinthetjük igazoltnak. A fauna kutatottságát közepesnek mondhatjuk. A hazai fajok elterjedési és gyakorisági viszonyainak értékelése még nem történt meg. Ezért egyelốre csak általánosságban beszélhetünk ritka fajokról. A faunalista tagjai közül ilyenek pl. az alábbiak: Conops vesicularis Linnaeus, 1761, Dalmannia dorsalis (Fabricius, 1794), Leopoldius coronatus (Rondani, 1857), Myopa polystigma Rondani, 1857, Thecophora distincta (Meigen, 1824), Zodion notatum (Meigen, 1804).

\section{A Somogyból ismert fajok jegyzéke}

\footnotetext{
Conops ceriaeformis Meigen, 1824 - Csiby

1981, Tóth 1995, Tóth (elókészületben)

Conops flavipes Linnaeus, 1758 - Csiby 1981, Tóth 1995

Conops quadrifasciatus Degeer, 1776 - Csiby 1981, Tóth 1992, 1995, Tóth (elókészületben)

Conops scutellatus Meigen, 1804 - Csiby 1981, Tóth 1992, 1995, Tóth (elókészületben)

Conops strigatus Meigen, 1824 - Tóth 1992

Conops vesicularis Linnaeus, 1761 - Tóth (elókészületben)
}

\author{
Dalmannia dorsalis (Fabricius, 1794) - \\ Csiby 1981 \\ Dalmannia punctata (Fabricius, 1794) - \\ Csiby 1981, Tóth 1992 \\ Leopoldius coronatus (Rondani, 1857) - Tóth \\ 1992 \\ Myopa buccata (Linnaeus, 1758) - Tóth \\ 1992, 1995, Tóth (elôkészületben) \\ Myopa fasciata Meigen, 1804 - Tóth 1995 \\ Myopa morio Meigen, 1804 - Tóth 1992, \\ 1995, Tóth (elókészületben)
}


Myopa occulta Meigen, 1824 - Tóth 1995, Tóth (elốkészületben)

Myopa polystigma Rondani, 1857 - Tóth 1995, Tóth (elókészületben)

Myopa stigma Meigen, 1824 - Tóth 1992,

1995, Tóth (elökészületben)

Myopa testacea (Linnaeus, 1767) - Tóth

1992, 1995, Tóth (elókészületben)

Physocephala vittata (Fabricius, 1794) - Tóth 1992, 1995, Tóth (elókészületben)

Sicus ferrugineus (Linnaeus, 1761) - Tóth 1992, 1995, Tóth (elökészületben)

Thecophora atra (Fabricius, 1775) - Csiby
1981, Tóth 1995, Tóth (elókészületben)

Thecophora distincta (Meigen, 1824) - Csiby 1981, Tóth 1995

Thecophora fulvipes (Robineau-Desvoidy, 1830) - Tóth 1992, 1995

Thecophora melanopa Rondani, 1857 - Tóth 1995, Tóth (elókészületben)

Thecophora pusilla (Meigen, 1824) - Tóth 1992, 1995, Tóth (elökészületben)

Zodion cinereum (Fabricius, 1794) - Tóth 1992, 1995, Tóth (előkészületben)

Zodion notatum (Meigen, 1804) - Tóth 1995, Tóth (elókészületben)

\section{Irodalom}

CsıBY, M. 1981: Adatok a Barcsi Borókás kétszárnyú (Diptera) faunájához - Dunántúli Dolg. Term. tud. Sorozat 2: 149-156.

TórH, S. 1992: Vegyes kétszárnyú (Diptera) adatok a Boronka-melléki Tájvédelmi Körzet faunájához - Dunántúli Dolg. Term. tud. Sorozat 7: 273-287.

Tóth, S. 1995: Adatok a Dráva mente kétszárnyú (Diptera) faunájához - Dunántúli Dolg. Term. tud. Sorozat 8: 161-172.

TóTH, S. Adatok Somogy megye kétszárnyú (Diptera) faunájához - Somogy Megy. Múz. Közlem., (elôkészületben)

\section{Checklist of thick-headed flies of Somogy county (Diptera: Conopidae)}

\section{SÁNDOR TóTH}

Approximately 40 thick-headed fly species are to be found in Hungary. According to the three papers (CSIBY 1981, TóTH 1992, 1995) summarizing the results of programs organized in Somogy county and to the manuscript (TóTH in print) based on unpublished data, at present 25 thich-headed fly species are proved to be existing in the county. The fauna is poorly known. From the list of the fauna, the following species are considered to be rather rare: Conops vesicularis Linnaeus, 1761, Dalmannia dorsalis (Fabricius, 1794), Leopoldius coronatus (Rondani, 1857), Myopa polystigma Rondani, 1857, Thecophora distincta (Meigen, 1824), Zodion notatum (Meigen, 1804).
Author's address:
Dr. Sándor TóTH
$\mathrm{H}-8420$ Zirc
Széchenyi u. 2.
HUNGARY 